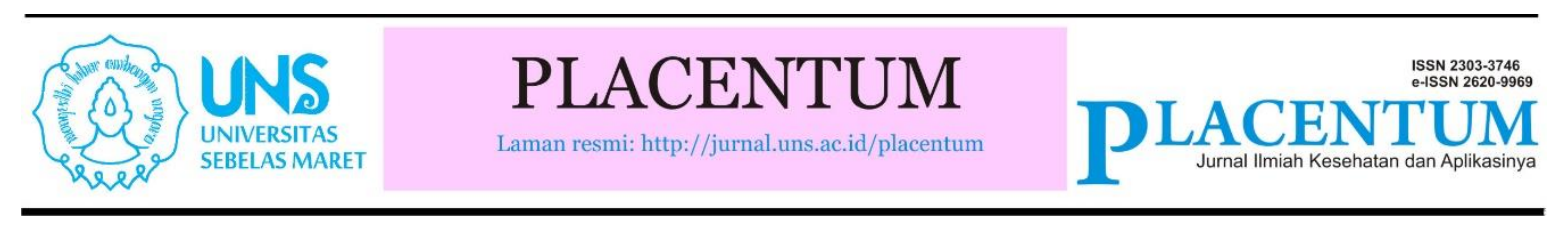

\title{
Effect of Age on Cadre Ability in Early Detection of High Domestic Violence
}

\author{
Yulianti* \\ Prodi Sarjana Kebidanan dan Pendidikan Profesi Bidan Universitas Medika Suherman, \\ Jl. Raya Industri Pasir Gombong Jababeka, Cikarang - Bekasi 17530 telp. (021) 89111110 \\ * Corresponding author \\ E-mail:yulianti@medikasuherman.ac.id
}

\begin{abstract}
Cases of Domestic Violence have a big impact on someone who experiences it even to the point of experiencing depression which even causes a sense of wanting to end his life ${ }^{[7]}$. Factors causing the high incidence of domestic violence are things that often occur such as economic factors, lack of communication, infidelity even to the point of personality characteristics being one of the causes ${ }^{[8]}$. The role of cadres is important in the process of empowering victims of domestic violence who play a role in community elements to overcome domestic violence events $^{[5]}$. The purpose of this study was to determine the factors that influence the level of cadre's ability to carry out early detection of domestic violence in the Work Area of the Sleman Health Center, Yogyakarta. This study used a cross sectional design involving a cadre population of 586 cadres with purposive sampling technique. Statistical analysis used the Eta Correlation test with the results of the statistical test of the ability of cadres in early detection of domestic violence with a significant value of 0.024 . The conclusion of the statistical test results in this study is that the age of cadres has a relationship with the ability of cadres to carry out early detection of domestic violence in the Godean II Health Center Work Area, Yogyakarta.
\end{abstract}

Keywords: Ability, Cadre, Domestic violence

\section{INTRODUCTION}

Domestic violence is increasingly seen in the world as a problem and a serious violation of human rights. No country in the world is safe from violence. violence every year mostly happens to women ${ }^{[9]}$.

Data on the characteristics of the triggers for violence against women reached $71 \%$ in the previous year. The most dominant domains are physical violence $41 \%$, sexual violence $31 \%$, psychological $15 \%$ and economic $13 \%{ }^{[6]}$.
Based on Migrant Workers Protection Agency data, there was an increase in cases that gave a fairly large number of victims and had been handled as many as $43.05 \%$ occurred in Yogyakarta, Sleman Regency as many as $28.41 \%$, Bantul Regency as much as $5.51 \%$, Gunung Kidul Regency $2.43 \%$ and the lowest $3.18 \%$ in Kulon Progo ${ }^{[4]}$.

The risks that will arise for the incidence of domestic violence often occur such as depression, attempted suicide and addiction to alcohol and narcotics. 
Similarly, female victims who become victims of domestic violence tend to behave quite dangerously, such as revenge to selfharm or suicide ${ }^{[1]}$.

In one of the Southeast African countries to form a strategy in the health sector to implement a sexual and reproductive health strategy to create an equality of rights by creating health cadres in the community. One of the duties of health cadres is to carry out this strategy by supporting the implementation of the National Sexual and Reproductive Health and Human Rights Strategy ${ }^{[2]}$.

With so many victims who are none other than women, the government plays an important role by providing female partners, namely cadres who will assist health workers to assist in empowering women with the aim that women have better health, especially as companions for victims of domestic violence ${ }^{[5]}$.

The cadres tend to be afraid to report the events experienced by the victims, and prefer to remain silent. In addition to not understanding and not having the heart to report perpetrators because most of them are closest people, there is also a lack of socialization about domestic violence. Therefore, these cadres indirectly have knowledge and lack of firm attitude in dealing with and dealing with domestic violence problems so that researchers are interested in conducting research because of the low understanding of cadres about domestic violence ${ }^{[10]}$.

\section{METHOD}

This study used a cross sectional design. The research was conducted in the Work Area of the Sleman Health Center, Yogyakarta. The study population used 586 health cadres who served in the working area of the Sleman Health Center. The sampling technique used purposive sampling accompanied by several inclusion criteria, namely cadres who were active in the last 1 year and had a minimum of 6 years of education and exclusion criteria were cadres who were not willing to become respondents. The number of samples used was 86 health cadres.

Bivariate analysis using Eta Correlation to determine the relationship between age and the ability of health cadres in early detection of domestic violence.

\begin{tabular}{l}
\hline RESULT \\
Univariate Analysis \\
Respondents in this study were health \\
cadres who were willing to become \\
respondents and had at least 6 years of \\
education in the work area of the Godean II \\
Health Center. Research subjects will be \\
grouped in the form of a frequency \\
distribution which has variables including \\
age which will be displayed in the form of \\
frequency and percentage. The results of the \\
frequency distribution can be presented in \\
the following table:
\end{tabular}

Table 1. Frequency Distribution of Characteristics on Respondents Age of Cadre Frequency Percentage

\begin{tabular}{ccc}
\hline $\begin{array}{c}\text { Mature (19- } \\
\text { 39) }\end{array}$ & 55 & $56,8 \%$ \\
Old (>40) & 40 & $43,2 \%$ \\
Total & 95 & $100 \%$ \\
\hline
\end{tabular}

Based on table 1, the age characteristics of the cadres are divided into two adults with 55 cadres $(56.8 \%)$ and 40 cadres $(43.2 \%)$.

\section{Bivariate Analysis}

One of the ways to analyze the bivariate test was to determine the relationship between age and the ability of health cadres to carry out early detection of domestic violence. The results of the bivariate test are presented in the following table: 
Table 2 Relationship between Age and Health Cadre Ability in Early Detection of Domestic Violence in the Work Area of Godean II Public Health Center, Yogyakarta. Directional Measures

\begin{tabular}{|c|c|c|}
\hline & & Value \\
\hline \multirow{2}{*}{$\begin{array}{l}\text { Nominal } \\
\text { by } \\
\text { Interval }\end{array}$} & $\begin{array}{ll}\text { Eta } & \text { Age } \\
& \text { Dependent }\end{array}$ & ,215 \\
\hline & $\begin{array}{l}\text { Ability } \\
\text { Dependent }\end{array}$ & ,042 \\
\hline
\end{tabular}

Based on Table 2, the results of statistical tests conducted through the Eta Correlation test showed that the results obtained were significant, namely the $p$ value (0.05) obtained was $<0.042$, which means that there is a relationship between age and the ability of health cadres to detect early domestic violence.

\section{DISCUSSION}

The results of the Eta correlation test on the ability variable obtained a $P$-value of $0.042(<0.05)$, which means that there is a relationship between the age variable and the ability of health cadres to carry out early detection of domestic violence.

With the results showing that age affects knowledge, therefore the cognitive influence is getting better. Cognitive function itself is influenced by several things such as language, thought development, memory development or memory ${ }^{[10]}$.

In line with research, high knowledge is also caused by factors supporting the age of respondents, most of whom are in the young adult age range where in this age range they have the ability to solve problems in a logical way by utilizing learning abilities and life experiences. With increasing age, the ability to receive stimuli decreases ${ }^{[16]}$.

Knowledge that is high influenced by the respondent's age factor which is mostly located in the young adult age range at which this age range they have the ability to solve the problems through logical way to take advantage of the ability to learn and experience life. As people get older, the ability to receive stimuli decreases. While the factors that influence the learning process are human factors, including age ${ }^{[1]}$. Increasing age increases one's metacognitive abilities (stages of memory, understanding, application, analysis and synthesis and evaluation) ${ }^{[10]}$.

Cognitive function that increases with the given stimulus gives an increase in memory, IQ, learning ability, comprehension ability, problem solving and decision making ${ }^{[11]}$.

Stimuli given through education provide good language function skills with parameters such as fluency, understanding, repetition and naming ${ }^{[12]}$.

A person's visual memory ability is influenced by age who have the ability to remember information obtained from information in the form of image [12]. Middle-aged and older adults tend to have higher health knowledge, skills and experience compared to younger adults ${ }^{[3]}$.

There is a significant visual decline in recognizing something that is seen at an older age compared to a younger age, this decline can also occur in emotional processing. Therefore, decreasing age is very important to increase one's age. Increasing age which also makes the visualization process will be disrupted due to rejection and a mild decline in the memory system ${ }^{[13]}$.

Age is one of the factors that affect knowledge, age affects one's grasping power and mindset, the older a person gets the more thinking power a person develops so that in the process of increasing the knowledge gained will also be better ${ }^{[14]}$.

There is a difference in knowledge in the age group between $20-30$ years. This age group can allocate time well so that it is fast in the process of transferring knowledge and is able to create an environment to communicate and exchange knowledge more efficiently ${ }^{[15]}$. 


\section{CONCLUSION}

Based on the results of the Eta Correlation Statistics test, the value of $p=$ $0.042<(0.05)$. This means that the ability of health cadres in carrying out early detection of domestic violence is strongly influenced by the age of health cadres in the work area of the Godean II Health Center, therefore the age of cadres is an influential factor in their ability to detect domestic violence early because age affects the thinking process.

\section{ACKNOWLEDGMENTS}

The author would like to thank all the support and I thank all parties involved in this study, both health cadres, midwives who helped the research process. The researcher also expresses his gratitude to the Godean II Health Center Work Area which has helped to complete all research processes.

\section{REFERENCE}

1. Shefet, D., Dascal-Weichhendler, H., Rubin, O., Pessach, N., Itzik, D., Benita, S., \& Ziv, A. (2007). Domestic violence: A national simulation-based educational program to improve physicians' knowledge, skills and detection rates. Medical

Teacher, 29(5).https://doi.org/10.1080/01421590 701452780

2. Veenman, M. V. J., \& Spaans, M. A. (2015). Relation between intellectual and metacognitive skills: Age and task differences. Learning and Individual Differences, 15(2), 159-176. https://doi.org/10.1016/j.lindif.2004.12

3. Kemenkes RI (2013). Pedoman Pengendalian Kekerasan Rumah Tangga. Jakarta: Kemenkes RI

4. Badan Perlindungan Pekerja Migran. (2015). Laporan Angka Kejadian Kekerasan. Yogyakarta

5. Bahrami, M., Shokrollahi, P., Kohan, S., Momeni, G., \& Rivaz, M. (2015). Assessing the Needs of Victim Women of
Domestic Violence Based on the Type and Causes of Violence: a Qualitative Study. Acta Medica Mediterranea, 31(1), 1411-1419.

6. Bell, J., Evans, J., Phoya, A., \& Humphrey, T. (2014). Developing a new public health cadre to meet the demands of midwifery care in Malawi. Perspectives in Public Health, 134(5), 248-249.

https://doi.org/10.1177/1757913914545 $\underline{293}$

7. Pemberdayaan Perempuan dan Perlindungan Anak, Pengendalian Anak, Pengendalian Penduduk dan Keluarga Berencana (2017). Laporan Kasus Kekerasan Pada Perempuan di Kabupaten Sleman. Yogyakarta.

8. Semahegn, A. and Mengistie, B. (2015) 'Domestic violence against women and associated factors in Ethiopia; Systematic review', Reproductive Health. Reproductive Health, 12(1). doi: 10.1186/s 12978-015-0072-1.

9. Soetoprawiro Koerniatmanto et al (2013). Training and Formation of Domestic Violence Cadre in Handling and Assisting Victims of Domestic Violence in Tarub District, Tegal Regency. Bandung; Katolik Parahyangan University.

10. Marlina, R. D. (2012). Relationship between Cognitive Function and Social Interaction Ability in Elderly in Mandan Village, Sukoharjo Community Health Center Work Area. Muhammadiyah Surakarta university.

11. Azizah. L. M. (2011). Elderly Nursing. Yogyakarta: Graha Ilmu

12. Laksmidewi, A. P. (2016). Cognitive Changes Associated with Normal and Pathological Aging. Hazzard's 
Geriatric Medicine and Georontology, 751-753; 46; 781; 757.

13. Hicks, R. E., Alexander, V., \& Bahr, M. (2017). Facial Recognition and Visual Processing as We Age: Using the Thatcher Illusion with Famous and NonFamous Faces. International Journal of Psychological Studies, 9(2), 26. https://doi.org/10.5539/ijps.v9n2p26

14. Notoatmodjo, S. (2010). Ilmu perilaku kesehatan. Jakarta: Rineka Cipta

15. Eftekhar, Z., Author, C., \& Shakeryari, R. (2018). Knowledge Management: The ability of Knowledge Sharing in Nursing and Midwi...: EBSCOhost, 16(1), 105-119. Retrieved from http://web.a.ebscohost.com/ehost/detail

16. Beier, M. E., \& Ackerman, P. L. (2015). Age, ability, and the role of prior knowledge on the acquisition of new domain knowledge: Promising results in a real-world learning environment. Psychology and Aging, 20(2), 341-355. https://doi.org/10.1037/0882-

7974.20.2.341 